\title{
Corneomandibular reflex in a patient with pontine hemorrhage without impaired consciousness
}

Marta Caballero-Ávila, MD, Eduard Juanola, MD, Artur Izquierdo, MD, Alejandro Martínez-Domeño, MD, and Joan Martí-Fàbregas, MD, PhD

Neurology ${ }^{\circledR}$ 2019;92:48-49. doi:10.1212/WNL.0000000000006701

Figure CT scan shows a bilateral pontine hemorrhage, predominantly right

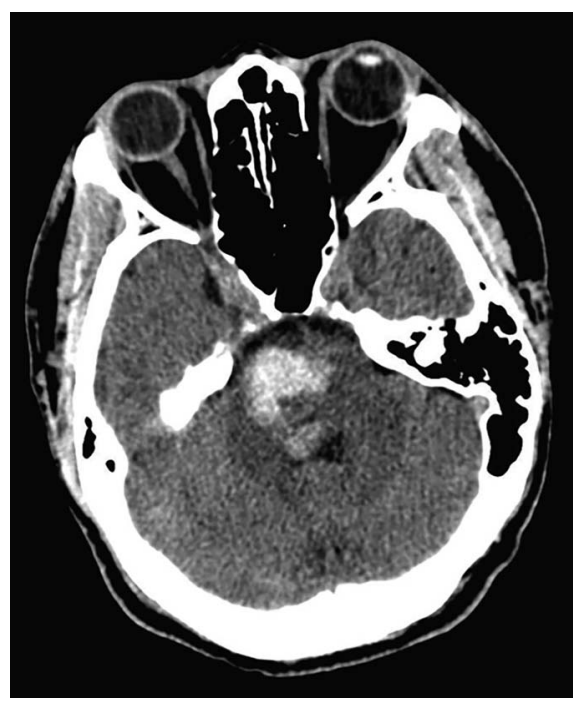

A 40-year-old man was admitted because of sudden loss of consciousness. CT scan showed a bilateral pontine hemorrhage, predominantly right (figure). Neurologic examination 19 days after onset showed ophthalmoplegia, anarthria, and tetraparesis. A prominent unilateral left corneomandibular reflex was observed and the patient was conscious and responsive to the examiner (video 1). This reflex consists of contralateral jaw deviation produced by corneal stimulation and has mostly been described in patients in coma. ${ }^{1}$ It helps to distinguish structural from metabolic processes in comatose patients. We emphasize that this sign can also be elicited in alert patients with destructive brainstem damage.

\section{Study funding}

No targeted funding reported.

\section{Disclosure}

The authors report no disclosures relevant to the manuscript. Go to Neurology.org/N for full disclosures.
Correspondence

Dr. Caballero-Ávila

mcaballeroa@santpau.cat 
Appendix 1. Author contributions

\begin{tabular}{ll}
\hline Name & Contribution \\
\hline $\begin{array}{l}\text { Marta Caballero- } \\
\text { Ála }\end{array}$ & $\begin{array}{l}\text { design and conceptualized study; analyzed the } \\
\text { data; drafted the manuscript for intellectual } \\
\text { content }\end{array}$ \\
\hline Eduard Juanola & $\begin{array}{l}\text { interpreted the data; revised the manuscript for } \\
\text { intellectual content }\end{array}$ \\
\hline Artur Izquierdo & $\begin{array}{l}\text { interpreted the data; revised the manuscript for } \\
\text { intellectual content }\end{array}$ \\
\hline $\begin{array}{l}\text { Alejandro } \\
\text { Martínez-Domeño }\end{array}$ & $\begin{array}{l}\text { interpreted the data; revised the manuscript for } \\
\text { intellectual content }\end{array}$ \\
\hline $\begin{array}{l}\text { Joan Martí- } \\
\text { Fàbregas }\end{array}$ & $\begin{array}{l}\text { design and conceptualized study; analyzed the } \\
\text { data; drafted the manuscript for intellectual } \\
\text { content }\end{array}$ \\
\hline
\end{tabular}

\section{Publication history}

Received by Neurology August 6, 2018. Accepted in final form September 20, 2018.

\section{Reference}

1. Guberman A. Clinical significance of the corneomandibular reflex. Arch Neurol 1982; 39:578-580.

\section{Disputes \& Debates: Rapid online correspondence}

The editors encourage comments on recent articles through Disputes \& Debates:

Access an article at Neurology.org/ $N$ and click on "COMMENT" beneath the article header. Responses will be posted within 3 business days.

Before submitting a comment to Disputes \& Debates, remember the following:

- Disputes \& Debates is restricted to comments about studies published in Neurology within the last eight weeks

- Read previously posted comments; redundant comments will not be posted

- Your submission must be 200 words or less and have a maximum of five references; reference one must be the article on which you are commenting

- You can include a maximum of five authors (including yourself)

\section{Visit the Neurology ${ }^{\circledR}$ Website at Neurology.org/N}

- More article-based content on home pages

- Streamlined menus and navigation

- Enhanced blog sections for specialty areas

- Same experience on desktop, tablet, and mobile devices

- Audio summaries of current issues

- Improved article reading experience; links more evident (pdf, analytics, social media)

- Neurology ${ }^{\circledR}$ Clinical Practice initiative "Practice Current" global surveys will be accessible across sites

f Find Neurology ${ }^{\circledR}$ on Facebook: http://tinyurl.com/neurologyfan

Follow Neurology ${ }^{\circledR}$ on Twitter: https://twitter.com/GreenJournal 


\section{Neurology}

\section{Corneomandibular reflex in a patient with pontine hemorrhage without impaired consciousness}

Marta Caballero-Ávila, Eduard Juanola, Artur Izquierdo, et al. Neurology 2019;92;48-49

DOI 10.1212/WNL.0000000000006701

This information is current as of December 24, 2018

\section{Updated Information \&} Services

References

Subspecialty Collections

Permissions \& Licensing

\section{Reprints}

including high resolution figures, can be found at: http://n.neurology.org/content/92/1/48.full

This article cites 1 articles, 0 of which you can access for free at: http://n.neurology.org/content/92/1/48.full\#ref-list-1

This article, along with others on similar topics, appears in the following collection(s):

\section{All Cerebrovascular disease/Stroke}

http://n.neurology.org/cgi/collection/all_cerebrovascular_disease_strok e

Clinical neurology examination

http://n.neurology.org/cgi/collection/clinical_neurology_examination Coma

http://n.neurology.org/cgi/collection/coma

Intracerebral hemorrhage

http://n.neurology.org/cgi/collection/intracerebral_hemorrhage

Information about reproducing this article in parts (figures,tables) or in its entirety can be found online at:

http://www.neurology.org/about/about_the_journal\#permissions

Information about ordering reprints can be found online:

http://n.neurology.org/subscribers/advertise

Neurology ${ }^{\circledR}$ is the official journal of the American Academy of Neurology. Published continuously since 1951, it is now a weekly with 48 issues per year. Copyright () 2018 American Academy of Neurology. All rights reserved. Print ISSN: 0028-3878. Online ISSN: 1526-632X.

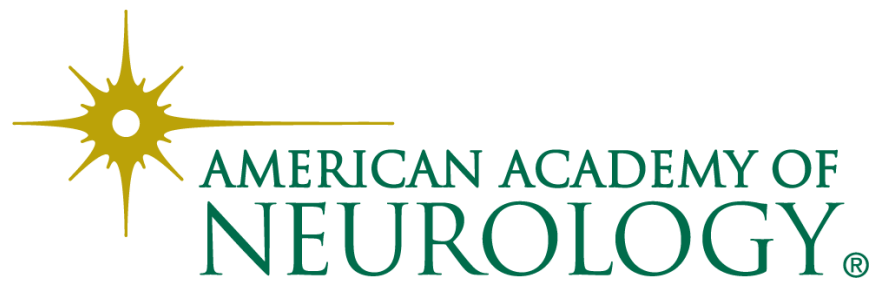

